RESEARCH ARTICLE

\title{
EXPLORATORY DIMENSIONS OF THE ATTITUDE TOWARD OCCUPATIONAL HEALTH'
}

DIMENSIONES EXPLORATORIAS DE LA ACTITUD HACIA LA SALUD OCUPACIONAL DIMENSÕES EXPLORATÓRIAS DA ATITUDE EM RELAÇÃO À SAÚDE OCUPACIONAL

Cruz García Liriosii

\section{Citation}

García-Lirios, Cruz (2019). Exploratory dimensions of the attitude toward occupational health. Dimensión Empresarial, 17(3). DOI: http://dx.doi.org/10.15665/dem.v17i3.1924

\begin{abstract}
In the context of health policies, the psychological processes of identity and stigma are a team that tries to explain assessment processes lifestyles related to vulnerable groups. Indeed, the aim of this study is to establish the validity and reliability of an instrument that measured four dimensions on a scale of attitudes. A cross - sectional and correlational study was conducted to establish the psychometric properties of the instrument with a non - probabilistic intentional sample of 258 students from a public university. The results show both dimensions as preponderant factors of attitude, but their inclusion in the construct was taken as part of a process of spontaneous activation; actions and risks that only carriers close to group can perform. Keywords: Identity, stigma, attitude, reliability, validity
\end{abstract}

\section{Resumen}

En el contexto de las políticas de salud, los procesos psicológicos de identidad y estigma son un conjunto que trata de explicar los procesos de evaluación de los estilos de vida relacionados con los grupos vulnerables. De hecho, el objetivo de este estudio es establecer la validez y confiabilidad de un instrumento que mide cuatro dimensiones en una escala de actitudes. Se realizó un estudio transversal y correlacional para establecer las propiedades psicométricas del instrumento con una muestra intencional no probabilística de 258 estudiantes de una universidad pública. Los resultados muestran ambas dimensiones como factores preponderantes de la actitud, pero su inclusión en el constructo se tomó como parte de un proceso de activación espontánea; Acciones y riesgos que solo las operadoras cercanas al grupo pueden realizar. Palabras clave: identidad, estigma, actitud, confiabilidad, validez.

\section{Resumo}

No contexto das políticas de saúde, os processos psicológicos de identidade e estigma são uma equipe que tenta explicar os processos de avaliação de estilos de vida relacionados aos grupos vulneráveis. De fato, o objetivo deste estudo é estabelecer a validade e a confiabilidade de um instrumento que mede quatro dimensões em uma escala de atitudes. Foi realizado um estudo transversal e correlacional para estabelecer as propriedades psicométricas do instrumento com uma amostra intencional não probabilística de 258 estudantes de uma universidade pública. Os resultados mostram ambas as dimensões como fatores preponderantes de atitude, mas sua inclusão no construto foi tomada como parte de um processo de ativação espontânea; ações e riscos que somente as operadoras próximas ao grupo podem executar. Palavras-chave - Identidade, estigma, atitude, confiabilidade, validade. 


\section{INTRODUCTION}

The health ocuppational is a public health problem due to the process of development. Occupatiomnal cycle comprises a standard period of 10 years that are still infected risky life styles as they do not change their behavior because of a symptom that requires them to self-care.

Thus, 30.1 million cases are adults, 16.8 million women and 1.5 million children. Sub - Saharan Africa has the largest number of carriers with $22^{\prime} 900,000$ while North Africa recorded 470,000 cases. In Latin America there 1,5000 thousand carriers and in Mexico only 200 thousand cases.

Both aspects, the process disproportionate increase in the regions seem to indicate that the problem originates in risk behaviors same as being influenced by the identity of carrier groups and non - carriers make a public health problem on the stigma.
In health sciences, close to sick groups are known as social support and are predominant factor in adherence to treatment, the main determinant variable of hospital health (Davis, Shell and King, 2012). In the case of nearby groups with not only styles are associated with risk, but risk attributed identities (Abbasi, Rafique Aziz and Hussain, 2013).

Identity and stigma are two psychosocial processes for purposes of this work will be understood as powers and biased in favor of a group of belonging with respect to another reference group (Cañizo and Salinas, 2010) elections.

Both definitions underlie consider a public health problem, which makes sense in a context; economic, political, social, welfare, symbolic, institutional, organizational, professional (see Table 1).

Tabla 1. Social context of public health

\begin{tabular}{|c|c|c|c|c|}
\hline Context & Dimensions & factors & interventions & Indicators \\
\hline Political & Commitment & Construction schedule & $\begin{array}{l}\text { Establishing } \\
\text { agreements }\end{array}$ & $\begin{array}{l}\text { Percentages of social and } \\
\text { agreements established } \\
\text { under local conditions }\end{array}$ \\
\hline Political & $\begin{array}{l}\text { Norms, meanings, } \\
\text { ideologies, visions }\end{array}$ & $\begin{array}{l}\text { Power, stigma, } \\
\text { discrimination, } \\
\text { influence }\end{array}$ & $\begin{array}{l}\text { Media coverage, } \\
\text { framing, awareness, } \\
\text { advocacy, } \\
\text { transformation }\end{array}$ & $\begin{array}{l}\text { Around percentages } \\
\text { related to the action of } \\
\text { the other beliefs nearest }\end{array}$ \\
\hline Material & Economy, praxis & $\begin{array}{l}\text { Poverty, capabilities, } \\
\text { criminalization }\end{array}$ & $\begin{array}{l}\text { Production, } \\
\text { redistribution, capacity, }\end{array}$ & $\begin{array}{l}\text { Percentages of exclusion } \\
\text { and marginalization care }\end{array}$ \\
\hline Relational & $\begin{array}{l}\text { Intra- and inter } \\
\text { communities, } \\
\text { organizations, } \\
\text { bodies }\end{array}$ & Capital participation & $\begin{array}{l}\text { education initiatives, } \\
\text { mobilization }\end{array}$ & $\begin{array}{l}\text { Percentages of } \\
\text { organization and } \\
\text { consultative, deliberative } \\
\text { or consensual } \\
\text { participation }\end{array}$ \\
\hline Institutional & $\begin{array}{l}\text { Structure, } \\
\text { incidence, } \\
\text { prevalence }\end{array}$ & $\begin{array}{l}\text { Vulnerability, } \\
\text { marginalization, } \\
\text { exclusion }\end{array}$ & $\begin{array}{l}\text { Specialized care, } \\
\text { focused treatment }\end{array}$ & $\begin{array}{l}\text { Costing and financing, } \\
\text { hospital structure } \\
\text { and modern facilities, } \\
\text { mortality, orphanhood } \\
\text { and risks; percentage } \\
\text { of cases diagnosed in } \\
\text { specific sectors with } \\
\text { standardized procedures }\end{array}$ \\
\hline
\end{tabular}




\begin{tabular}{|l|l|l|l|l|}
\hline organizational & $\begin{array}{l}\text { Provision, capacity, } \\
\text { quality }\end{array}$ & $\begin{array}{l}\text { Climate relationships } \\
\text { and tasks }\end{array}$ & Reengineering, synergy & $\begin{array}{l}\text { Strategic alliances in } \\
\text { training volunteer } \\
\text { management and } \\
\text { promotion processes, } \\
\text { percentage of } \\
\text { applicant's diagnosis } \\
\text { and monitoring of cases, } \\
\text { risk communication and } \\
\text { health promotion }\end{array}$ \\
\hline Asistencial & $\begin{array}{l}\text { Knowledge, } \\
\text { behavior, adhesion, } \\
\text { representation, } \\
\text { happiness, } \\
\text { influence }\end{array}$ & $\begin{array}{l}\text { Promotion, } \\
\text { management, quality of } \\
\text { life and subjective well } \\
\text { - being }\end{array}$ & $\begin{array}{l}\text { Channeling, } \\
\text { monitoring, } \\
\text { mediation, promotion, } \\
\text { management }\end{array}$ & $\begin{array}{l}\text { Percentage of self - care } \\
\text { and coping around } \\
\text { the problem, forming } \\
\text { positive attitudes }\end{array}$ \\
\hline
\end{tabular}

Source: Mannell, Comish and Russell (2014)

Referring to attitudes, identity is a consequence of a deliberate, planned and systematic election (Summer, 2011). In this sense, there are three attitudinal theoretical frameworks that explain ingroup favoritism to the detriment of the outgroup known as ethnocentrism, although a conflict within the group of belonging generate an altercentrismo (Chacon, Barrantes, Comerfold and McCoy, 2014).

The theory of reasoned action (TAR) argue that identity and stigma are products processing general information about a group of belonging in contrast to the allocations to a reference group (Ferragut and Ortiz, 2013). In this conceptual model, beliefs surrounding process the information, but are biased attitudes who will determine the choice of a group (Uribe and Orcasita, 2011). These are categories in which the information is concentrated to perform a specific action that celebrates the ingroup and the out group circumvented (Garcia and Rodriguez, 2014).

However, the deliberate action resulting, categorized general information, not always anticipate specific behaviors and perceptions rather require control or perceived behavioral controls (Jouen and Zielinski, 2013).

Thus, the Theory of Planned Behavior (TCP) assumes that only the defined information and processing both beliefs and perceptions specify the information in such a way that anticipate specific behaviors (Klaus, Pineres and Hincapie, 2010).

Thus, the TAR and TCP, identity and stigma are consequences of having deliberately processed, planned and systematic information concerning a group close to an individual after being contrasted with information on other distant groups to the same individual (Rodriguez, 2013).

Although attitudes have been considered associations between evaluations from group categories, Espontáneo Processing Theory (TPE) argues that it is rather the arbitrary processes attitudes, spontaneous or semi (Albacerrin and Wyer, 2011).

TPE, unlike the TAR and TCP posed a deliberate, planned and systematic, considers that this information is maintained in memory long and short term, as well as its procedural phase (Mardones and Guzman, 2011). Thus, the information is stored and is in a dormant state to be activated when some stimulus recovers and associated with an improvised behavior (Hughes and Barnes, 2011).

The identity and stigma from the perspective of the TPE, are part of arbitrary, spontaneous or semi automatic process that characterizes attitudes (Solat, Velhal, Mahajan Rao and Sharma, 2012). In this regard, it is noted that identity is a negative or positive 
attitude for or against a group and stigma is a biased evaluation of the attitudinal and identity process, but for some reason is dormant and does not materialize as behavior until a stimulus reactivates the discretion of the individual to categorize related to carriers of a disease (Becerra, Chunga, Palomino, Arevalo, Nivin, Portocarrero, Carbajal, Thomas, Caro, Astocaza, Torres, Carbajal groups Pinto, Moras, Munayco and Gutierrez, 2012)

Since the TAR, TCP and TPE is possible to construct a theoretical framework in which coexist both deliberate processes with spontaneous, planned discretionary, systematic with semiautomatic (Selesho and Modise, 2012). In this model, information does not flow from one side to another or interconnects from one end to another but is in all the cognitive structure of the individual showing the formation of a network (Villa, 2010).

Attitudinal Theory Network (TRA) argues that both identity and stigma are not only correlated with attitudes, but also are structural nodes from which the information is renewed to form new nodes; associations between categories and evaluations about information concerning the ingroup and outgroup (Mendez, Rojas y Moreno, 2012).

Psychological studies of attitudes, identity and stigma pose a cognitive network to explain the relationships between groups and people living with ocuppational health (Castillo and Chinchilla, 2011).

Petro (2013) considers the cognitive network is a process of social responsibility in which carriers not only show a self-care, but also spread their experiences to prevent re-infections or infections that lead to a public health problem. Giraldo (2013) found in the expression of the disease a network structure associated with social responsibility and solidarity with carriers in terminal phase, but Mendez (2013) showed a network of determining symbols recruitment of victims of sexual exploitation who developed behaviors of underestimation, risk and recidivism. Among the risky sexual behavior is coitus interruptus Petracci (2011) associated with a network of beliefs about invulnerability.

In this sense, Serrano (2011) warns that when couples establish a communication network, its decisions are carried out by consensus, but when only one - way communication is established, men women delegated the responsibility for contraception. Meanwhile, Hernandez (2013) found that when a group is exploited by pimps, the latter set speeches legitimizing the superiority of residents or natives regarding migrants. In this sense, Aramayo (2011) through an inventory of experiences of sexual assault established a link with current sexual experiences, but Rivers (2011) found that victims are not always considered and exploited rather their religious beliefs around sin which affect their sexual behavior.

\section{Method}

Design. An exploratory, transversal and correlational study was conducted.

Sample. A nonrandom selection of 258 students from a public university in the State of Mexico was conducted. The criterion of choice was to have enough knowledge occupational health and have interacted with carriers, their relatives or friends.

Sex. The $49 \%$ of respondents were women $(M=339.45$ dollars monthly income and $\mathrm{DE}=21.37$ dollars), $48 \%$ were male ( $\mathrm{M}=384.58$ dollars and $\mathrm{DE}=19.36$ dollars) and 3\% did not answer

Age. The $51 \%$ are between 22 and 29 years $(M=326.38$ dollars monthly income and SD=21.25), 37\% are between 18 and 22 years $(M=273.29$ and $D E=18,0), 9 \%$ are under 18 years $(M=220.13$ and $D E=10.6), 3 \%$ did not answer

Group. 63\% said they did not belong to any group $(M=257, \$ 27$ of monthly income and $S D=19.08)$, 
$34 \%$ said that if they belonged to a group $(M=345,24$ and $\mathrm{DE}=17.20), 3 \%$ did not answer

Instrument. The Attitudes Scale Towards Occcupational Health was used Garcia (2013) which includes 28 statements about negative or positive, favorable or unfavorable to nearby groups occupational health and their lifestyles provisions behaviors risk and vulnerability. Each statement includes six response options ranging from $0=$ "not at all likely" to $5=$ very likely. The dimension of identity measures attitudes toward a group close to people living occupational healt compared to groups considered distant and reached a reliability (alpha $=0.718$ ) higher than the minimum necessary. The dimension of stigma measures attitudes toward lifestyles and risk behaviors and vulnerability to sexual exploitation associated with nearby groups with occupational health with respect to distant groups reaching reliability (alpha $=0.702$ ) than required. The overall scale had an internal consistency (alpha = 0.780 ) than the subscales of identity and stigma.

Procedure. Adjust the original instrument at the university level considering the findings reported in the state of knowledge and public health context.
Students were surveyed in the lobby of the medical and sexual orientation prior informed consent and warning that the study results would not affect their academic status. Data were processed in SPSS version 20 and AMOS version 4.0

Measures of central tendency and dispersion measures for descriptive instrument data and alpha coefficients were estimated for reliability and values exploratory factor analysis of principal components with varimax rotation, adaptation and sphericity. The values above 0.70 were considered as evidence of internal consistency and the top 0,600 KMO values were taken as evidence of suitability with significant levels less than 0.05 sphericity case were considered. The above 0.300 factor weights were assumed as evidence of construct validity.

\section{Results}

Table 2 shows values above 0.70 for the items that were measured by two subscales concerning the identity and stigma as preponderant factors attitude towards occupational health which was established above 0,300 same factor that explained $43 \%$ and $57 \%$ of the total variance.

Tabla 2. Social context of public health

\begin{tabular}{|ll|l|l|l|l|l|l|l|}
\hline R & M & S & K & A & F1 & F2 & F3 & F4 \\
\hline R1 & 2,48 & 0.17 & 0,134 & 0.713 & 0.482 & & & \\
\hline R2 & 2.30 & 0.13 & 0,143 & 0,729 & 0.493 & & & \\
\hline R3 & 2.94 & 0.18 & 0,176 & 0.794 & 0.493 & & & \\
\hline R4 & 2.60 & 0.09 & 0,187 & 0,739 & 0.491 & & & \\
\hline R5 & 2,64 & 0.11 & 0,198 & 0.712 & 0.402 & & & \\
\hline R6 & 2.83 & 0.10 & 0,132 & 0,739 & 0.536 & & & \\
\hline R7 & 2,49 & 0.13 & 0,174 & 0.725 & 0.406 & & & \\
\hline R8 & 2.83 & 0.15 & 0,143 & 0,739 & & 0.514 & & \\
\hline R9 & 2.96 & 0,94 & 0,175 & 0.748 & & 0.578 & & \\
\hline R10 & 2.77 & 0.85 & 0,164 & 0.745 & & 0.351 & & \\
\hline R11 & 2,49 & 0,71 & 0,143 & 0.741 & & 0.362 & & \\
\hline R12 & 2,61 & 0,39 & 0,132 & 0.756 & & 0.462 & & \\
\hline R13 & 2.84 & 0,31 & 0,145 & 0.772 & & 0.468 & & \\
\hline
\end{tabular}




\begin{tabular}{|ll|l|l|l|l|l|l|l|}
\hline R & M & S & K & A & F1 & F2 & F3 & F4 \\
\hline R14 & 2.90 & 0,48 & 0,175 & 0.704 & & 0.591 & & \\
\hline R15 & 1,04 & 0,57 & 0,187 & 0.714 & & & 0.493 & \\
\hline R16 & 1.05 & 0,26 & 0,198 & 0.726 & & & 0.491 & \\
\hline R17 & 1,92 & 0,83 & 0,134 & 0.701 & & & 0.384 & \\
\hline R18 & 1,06 & 0,93 & 0,154 & 0.735 & & & 0.412 & \\
\hline R19 & 1,07 & 0.99 & 0,134 & 0.794 & & & 0.485 & \\
\hline R20 & 1.01 & 0.80 & 0,176 & 0.752 & & & 0.384 & \\
\hline R21 & 1,82 & 0,74 & 0,174 & 0.734 & & & 0.461 & \\
\hline R22 & 1,16 & 0,69 & 0,131 & 0.705 & & & & 0.401 \\
\hline R23 & 1,19 & 0.36 & 0,145 & 0.772 & & & & 0.493 \\
\hline R24 & 1,06 & 0,46 & 0,175 & 0,785 & & & & 0.524 \\
\hline R25 & 1.01 & 0,51 & 0,197 & 0.705 & & & & 0.395 \\
\hline R26 & 1,07 & 0.55 & 0,135 & 0,715 & & & & 0,330 \\
\hline R27 & 1,49 & 0,64 & 0,162 & 0,762 & & & & 0,536 \\
\hline R28 & 1,53 & 0,52 & 0,143 & 0,784 & & & & 0,531 \\
\hline
\end{tabular}

$\mathrm{R}=$ Reactive, $\mathrm{M}=$ Median, $\mathrm{S}=$ Standard Deviation, $\mathrm{K}=$ Kurtosis, $\mathrm{A}=$ Alpha removed value item. Multivariable Bootrsrtrap = 0,000; Multivariable Kurtosis $=1.304 ; \mathrm{KMO}=0.721$; Bartlett $[\chi 2=18.33(18 \mathrm{gl}) \mathrm{p}=0.000]$, Factor $1=$ Attitude towards the identity ( $23 \%$ of the total variance explained), Factor $2=$ Attitude toward stigma ( $17 \%$ of the explained variance), Factor $3=$ Attitude toward image ( $13 \%$ of the explained variance), Factor $4=$ Attitude toward reputation ( $7 \%$ of the explained variance). Source: Elaborated with data from the study

The internal consistency and construct validity show that the instrument can be replicated in other contexts with other samples, but the latter must be university students since the selection of the sample was not random.

Once the factors that explained $60 \%$ of the total variance explained were explained, we proceeded to observe the linear relationships between them to anticipate their structure and the emergence of a second order factor common to the four relative first-order factors to the identity, the image, the reputation and the stigma of groups around occupational health (see Table 3).

Tabla 3. Correlations and covariations

\begin{tabular}{|ll|l|l|l|l|l|l|l|}
\hline \multicolumn{2}{|c|}{ F1 } & F2 & F3 & F4 & F1 & F2 & F3 & F4 \\
\hline F1 1,000 &, $327^{*}$ &, $439^{* *}$ &, $320^{*}$ & 1,896 &, 453 &, 435 &, 439 \\
\hline F2 & 1,000 &, $314^{*}$ &, $431^{* * *}$ & & 1,865 &, 325 &, 471 \\
\hline F3 & & 1,000 &, $345^{* *}$ & & & 1,984 &, 327 \\
\hline F4 & & & 1,000 & & & & 1,943 \\
\hline
\end{tabular}

$\mathrm{F} 1=$ Attitude towards the identity, F2 = Attitude toward stigma, F3 = Attitude toward image, F4 = Attitude toward reputation: $* p<, 01 ; * * p<, 001 ; * * * p<, 0001$ 
The values of association between the factors, together with the percentage of total variance explained, suggest a common factor of second order that would explain the formation of attitudes towards occupational health, but the adjustment and residual parameters $\int_{x} 2=324,3$ (54gl) $p<$ ,01; GFI = ,997; CFI = ,995; RMSEA = ,008 J warn the non-rejection of the relative null hypothesis to the significant differences between the theoretical relations of the variables with respect to the empirical relationships, suggesting the inclusion of explanatory constructs of attitudes such as beliefs and perceptions (see Figure 1).

\section{DISCUSSION}

This study has established the validity and reliability of an instrument that measures attitudes toward identity and stigma of nearby groups with occupational health in a context in which the media, especially television was assumed as the source more prominent in terms of lifestyles and risk behaviors and vulnerability to sexual exploitation by those who interact with people living occupational health information. parents and children and concluded that not only the sexual subject was taboo but was also guided by a gender female rather than a male gender identity. In this sense, the present study warns that gender identity would be linked with the stigma, as it is two information nodes that although they were influenced by media guide the formation of attitudes towards the occupational health.

However, the report Afanador (2014) noted a bias concerning gender identity at the time of between

Source: Elaborated with data study

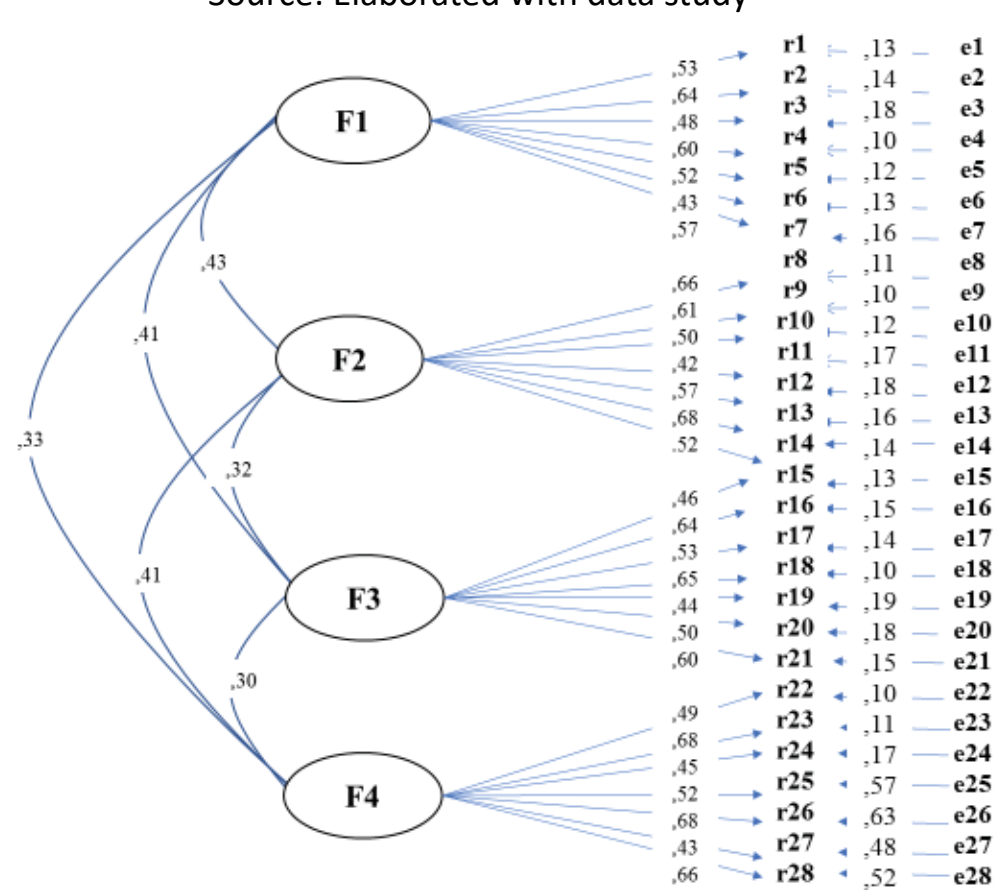

Figure 1. Structural Equation Modellling 
Thus, Hurtado, Avandaño and Moreno (2013) argue that teens who start their sex are more influenced by their peers than by their parents, teachers, social groups or digital networks. That is, the identity seems to be a process that not only explicit sexual preference, but also practice and frequency of it when improvising or planning a laboral act. In the present study only established that respondents not only distinguish their group belonging to the reference group in question (family and friends), but also warn a trend of attributes that makes them evaluate these groups as different to associating lifestyles and risk behaviors themselves a vulnerable to sexual exploitation sector.

Finally, with regard to the study by Garcia (2013) in which the group of health professionals stigmatized attention to families and people living occupationa health as a vulnerable group that is owed to respond differently to other groups of relatives and patients, this paper considers the identity not only is evaluated by respondents but is also linked with associations that put vulnerable groups at risk practices and labours.

However, this paper does not explain how the identity and stigma are nodes attribution information concerning lifestyles and risk behaviors in an environment, but if evidence both identity and stigma are components a construct on attitudes towards groups related with occupational health. That is, the study may or may not verify the identity and stigma are nodes where it is concentrated or generates information, but it opens the discussion on the importance of observing the relationship between vulnerable groups, marginalized or excluded around carriers as these are part of a social support largely determines adherence to treatment.

\section{CONCLUSION}

The contribution of this work is the state of knowledge have established the validity and reliability of an instrument that measures two preponderant psychosocial factors in shaping attitudes towards close groups with occupational health. According to the theory of spontaneous processing, memory not only protects information concerning pccupational health, styles and risk behaviors of vulnerable groups, but also such information is activated spontaneously or arbitrarily to carry out impromptu behaviors that explain the self watch out. In this sense but indicate the emergence of a psychosocial process relating to power or social influence around sexuality.

\section{REFERENCIAS}

Abbasi, A., Rafique, M., Aziz \& Hussain W., W. (2013). Knowledge, attitudes of university students of the state of Azad Kashmir (Pakistan) Journal \& Research, 5, 157-162.

Afanador, A. (2014). Special features regarding the formation of sexuality in adolescents. Hispano - American Notebooks Psychology, 13 (2), 91-104

Albacerrin, D. \& Wyer, R. (2011). Elaborative and non elaborativeproccess to behavior related communication. Personality and Social Psychology Bulleting, 27, 691-705

Aramayo, S. (2011). Therapy focused on solutions applied to sexual assault. Case study. Ajayu Journal, 9, 132-168

Becerra, V., Chunga, N., Palomino, C. Arevalo, T., Nivin, J., Portocarrero, L., Carbajal, P., Thomas, B., Caro, M., Astocaza, L., Torres, L., Carbajal, E., Pinto, A., Moras, M., Munayco, M. \& Gutierrez, C. (2012). Association between knowledge of Peruvian women and their attitudes towards infected people. Peruvian Journal of Epidemiology, 16: 1-8

Hurdle, E. \& Salinas, F. (2010). Alternative sexual behaviors and permissiveness in university students. Teaching and Research in Psychology. 15, 285-309 
Castillo, A. \& Chinchilla, Y. (2011). The experience of the school of psychology at the University of Costa Rica in addressing commercial sexual exploitation. Latin American Journal of Human Rights, 22, 121-151

Chacon, M., Barrantes, K., Comerfold, M. \& McCoy, C. (2014). Exuales s practices and knowledge among drug users in a low - income community in Costa Rica. Health and Drug, 14 (1), 27-36

Davis, M., Shell, A. \& King, S. (2012). Assessing pharmacist 'perspectives of the care infected Patients in Alabama. Pharmacy Practice, 10, 188-193

Ferragut, M. \& Ortiz, M. (2013). Psychological values as protective factors in preadolescents against sexist attitudes. Psicothema, 25, 38-52

Garcia, C. (2013). Attitude of social workers to carry in community health centers. Health \& Society, 4 (1), 60-68

Garcia, I. and Rodriguez, M. (2014). Living situation and treatment adherence among women and youth in San Luis Potosi. Acta Universitaria, 24 (4), 3-14

Giraldo, I. (2013). Cyber -bodies. Youth and sexuality in the postmodern Investigative News in Education, 13: 1-22

Hernandez, I. (2013). Migration, feminization and trafficking in illegal migration flows in Mexico's southern border Digital University Magazine, 14: 1-15

Hughes, S. \& Barnes, D. (2011). The dominance of associative research theorizing in implicit attitude: propositional and behavioral alternatives Psychological Research, 6, 465-498.

Hurtado, N., Avandaño, M. \& Moreno, F. (2013). Teenage pregnancy. Between failure and informative psychic achievement Journal of Psychology at the University of Antioquia, 5 (1), 93-102

Jouen, F. \& Zielinski, S. (2013). Commercial of children in tourism destinations. Knowledge, attitudes and prevention of tourist services in Tananga, Colombia. Journal of Tourism and Cultural Heritage, 11, 121-134

Klaus, A., Piñeres, J. \& Hincapie, A. (2010). Subjectivations language and parody. Reflections on experts' speeches on commercial of children and adolescent girls Latin American Journal of Social Sciences, Childhood and Youth, 8, 269-291

Mannell, J., Cornish, F. \& Russell, J. (2014). Evaluating social outcomes interventions: a critical assessment of contemporary indicators frameworks Journal of International Society. 17 (1), 1-11 DOI: 10.7448 / IAS.17.1.19073

Mardones, R. \& Guzman, M. (2011). Toward comprehensive treatment from the psychosocial model in children and adolescents who are sexually exploited. Scientific Journal of Psychology, 2, 27-47

Mendez, M. (2013). Try: invisible slavery in Costa Rica. Study of five cases. Revista Costarricense Psychology, 32, 109-135

Mendez, R., Rojas, M. \& Moreno, D. (2012). Commercial sexual exploitation of children: life paths abuse Research and Development, 20, 450-47.

Petro, B. (2013). Attitudes and views of teachers towards student sexual relationships in secondary school in Tanzania. Academic Research International, 4, 232-241

Rivers, M. (2011). The uses of trafficking in Central America: migration, gender and sexuality Central American Studies Yearbook. 37, 87-103

Rodriguez, D. (2013). Advanced chronic disease, mental illness and general system of social security in health. Journal of Psychology at the University of Antioquia, 5 (1), 75-92

Selesho, J. \& Modise, A. (2012). Strategy (ies) in daling with ours schools: changing the lenses Journal of Human Ecology, 38, 181-189.

Solat, S., Velhal, G., Mahajan, H., Rao, A. \& Sharma, B. (2012). Assesment of knowledge and attitude of rural population in professor.uamex.mx Raigad Distrit, India. Journal of Dental and Medical Science. 1 31-45

Summer, L. (2011). The theory of planned behavior and the impact of the past behavior. International Business and Economic Research Journal, 10, 91-110

Uribe, A. and Orcasita, L. (2011). Evaluation knowledge, attitudes, susceptibility and self - efficacy against health professionals. Advances in Nursing. 29, 271-284

Villa, E. (2010). Anthropological study about prostitution. Cuicuilco, 17, 157-179 


\section{NOTAS FINALES DEL ARTÍCULO}

'Article derived from the project "Corporate Governance of Occupational Health" with registration number ATNCGL-2017-001, funded by the Academic Transdisciplinary Network, Universidad Autónoma del Estado de México, Toluca, www.uaem.mx. Reception date 06/01/2019. Acceptance date 05/15/2019.

ii Postdoctoral student in Complexity Sciences, Center for Political and Social Studies, https://ceps.edu.mx/. Research profesor Universidad Autónoma del Estado de México, Toluca. Email: cgarcial213@pofesor.uaemex.mx

Este artículo fue editado en la Facultad de Contaduría y Administración, www.unam.mx/ de la Universidad Nacional Autónoma de México, www.unam.mx/, Ciudad de México y la Facultad de Ciencias Administrativas, Económicas y Contables, https://www.uac.edu.co/facultades/facultad-ciencias-administrativas-economicas-y-contables, de la Universidad Autónoma del Caribe, www.uac.edu.co, Barranquilla. 